Global Conferences Series:

Social Sciences, Education and Humanities (GCSSSEH), Volume 3, 2019

The $1^{\text {st }}$ International Conference on Education, Social Sciences and Humanities

DOI: https://doi.org/10.326/hum0208

\title{
Empathy Profile Based on Gender in IV Graders of Elementary School Students
}

\author{
Wirda Hanim ${ }^{1 *}$, Anan Sutisna ${ }^{2}$ \\ 1,2 Universitas Negeri Jakarta, Jakarta, Indonesia, \\ (*) $\square$ wirdahanim10@gmail.com
}

\begin{abstract}
This study deals with the profile of empathy. The method used survey method. The respondents obtained by using convenience sampling technique. The respondents involved were $643 \mathrm{IV}$ graders of elementary school students consisting of 322 male students and 321 female students. The results obtained from the lowest aspects based on the overall analysis are aspects of cognitive empathy by $62.4 \%$ of respondents in the low category, $37.6 \%$ in the moderate category, and $0 \%$ in the high category. The affective aspect has a fairly average distribution of $39.3 \%$ of respondents in the low, $43 \%$ in the medium, and $16,8 \%$ in the high category. The most moderate category of prosocial motivation is $50.5 \%$, the low category is $29.9 \%$ and the high is $19.6 \%$. The low contribution of cognitive aspects was caused by male respondents $70.2 \%$ in the low category while in women only $54.5 \%$. In the affective aspect the contribution of the two is relatively no significant difference. In the aspect of male prosocial motivation $32 \%$ of the respondents are in the low category while women are less than $4.3 \%$ and $3.8 \%$ women are more than men in the high category.
\end{abstract}

Keywords: Empathy, Gender, Profile, Students

\section{Introduction}

Empathy is a basic human capacity that supposedly serves to regulate relationships, supporting collaboration and group cohesion (Rieffe, Ketelaar, \& Wiefferink, 2010). The perceived empathy must also be expressed and the person who does empathy must be able to get rid of his own values, but he must not be dissolved in the values of others. Empathy is an individual's ability to provide emotional responses according to expected situation.

Empathy can be defined as the ability to feel or imagine another person's emotional experience. The ability to empathize is an important part of social and emotional development, affecting an individual's behavior toward others and the quality of social rela-tionships. we begin by describing the development of empathy in children as they move toward becoming empathic adults. We then discuss biological and environmental processes that facilitate the development of empathy (Firdayani, 2015).

The definition of empathy seems simple, but it contains various aspects in it. Empathy consists in three aspects, namely affective empathy, cognitive empathy and prosocial motivation (A.P. et al., 2015). Affective empathy, also known as emotional transmission, is a process in which the emotional state of others causes the observer's level of arousal. Cognitive empathy develops when children

Copyright $@$ ( 2019, the Authors. Published by Redwhite Press.

Page | 138

This is an open access article under the CC BY-NC license

(http://creativecommons.org/licenses/by-nc/4.0). 
grow up and involve a more sophisticated understanding of the emotional state of others(BaronCohen \& Wheelwright, 2004). Children begin to understand why others are upset. Understanding the emotions of others has a different purpose. Empathy is needed to encourage prosocial behavior: voluntary behavior to benefit others (Jolliffe \& Farrington, 2006). Therefore, empathy is often referred to as 'social glue' in relationships (Eisenberg \& Miller, 1987).

The development of empathy is influenced by genetic and environmental factors. In addition to environmental genetic factors also have an influence on the development of empathy. The results showed a lack of empathy in children was caused due to threats or physical punishment, parental rejection, children from families where mothers often experience violence by fathers, excessive rewards. This is caused by everything that is seen, heard and felt by children.

Lack of empathy results in the emergence of aggressive behavior for individuals. Bullying actors have low empathy and tend to have an attitude to dominate others (Olweus, 1997). A well-developed empathy will reduce bullying behavior (Fatimatuzzahro, Nimah Suseno, \& Irwanto, 2018a).

Other research results address the importance of empathy. The results of the study show that the basic helping ability (alturism) is primarily empathy (Nurhidayati, 2012) and empathy is also closely related to the emergence of friendly attitudes (Nurhidayati, 2012). Children who have good empathy are expected to grow into individuals who do not want to hurt others.

The results of the above research show that there is a close relationship between low empathy and the emergence of aggressive behavior and also shows the existence of empathy associated with the emergence of behavior. Seeing the impact of the existence of empathy on someone, the development of empathy from an early age is important to note. So, in this study it is important to do a survey to find out the profile of students.

\section{Method}

This study used a survey method. The Research located in DKI Jakarta. The samples taken were 643 respondents from IV graders students from 16 schools in DKI Jakarta. The sampling technique used convenience sampling. The instrument was used to obtain an overview of the data, namely the Empathy Questionnaire Children and adolescents (EmQue-CA) (Overgaauw, Rieffe, Broekhof, Crone, \& Güroglu, 2017).

The procedure for conducting research begins with translating questionnaires into Indonesian. Followed by giving direction to the surveyor in distributing instruments. The surveyor is a IV graders teacher at the respondents' school. After that, surveyor gives the instrument to students and the results are tabulated and analysed by using SPSS. The analysis technique, used to process research results, is using descriptive statistics namely mode.

\section{Results and Discussion}

Empathy is an important aspect of life. Spirit of juvenile delinquency, cases of brawls, abuse and even murders among teenagers are indicative of a lack of empathy. According to (Overgaauw et al., 2017), Empathy plays a crucial role in healthy social functioning and in maintaining positive social relationships. The results of previous studies state that empathy Empathy that develops well will reduce bullying behavior (Fatimatuzzahro, Nimah Suseno, \& Irwanto, 2018b).

The empathy measurement tool has been widely developed, one that is quite widely used and has been validated across countries is the EmQue-CA scale. This instrument measures empathy into three aspects of empathy, namely affection, cognitive and prosocial motivation. These three aspects are the basis for determining the profile of respondents of elementary students in DKI Jakarta. 


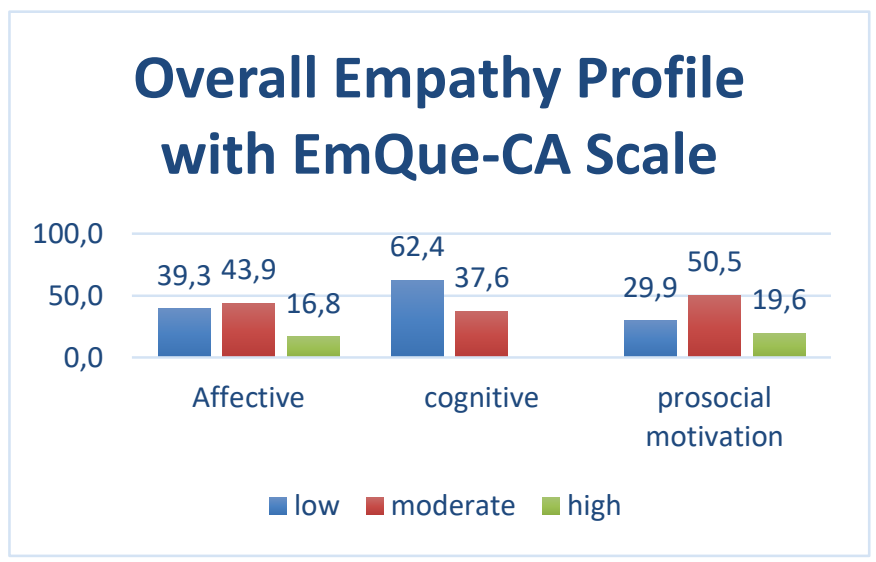

Figure 1 Overall Empathy Profile Graphics

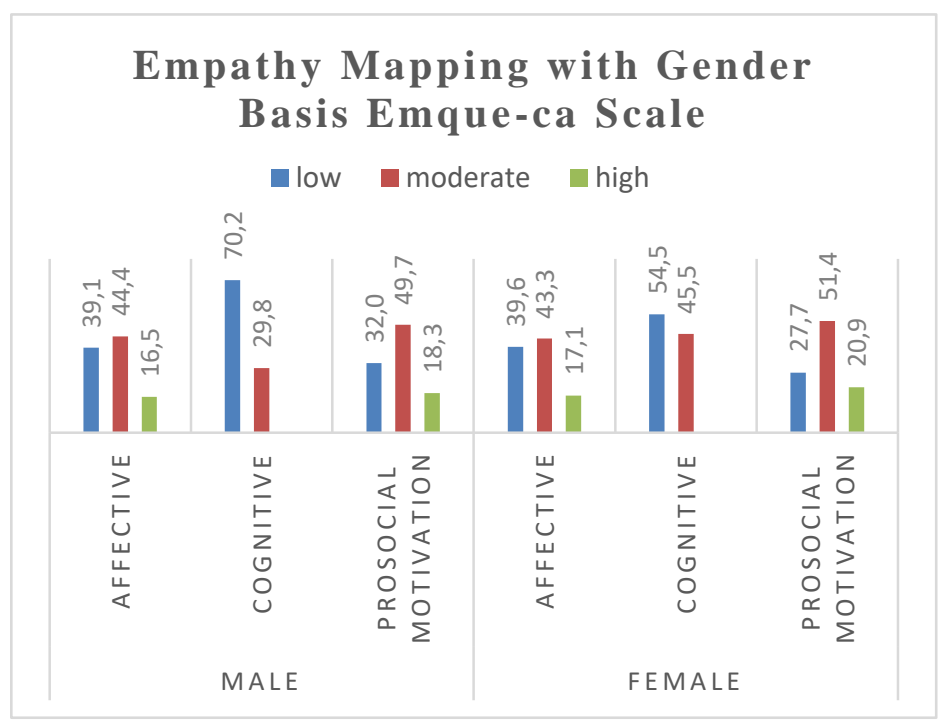

Figure 2 Emphaty Mapping with Gender Basis Graphics

On the cognitive aspects as shown in the empathy profile chart above has a percentage of $62.4 \%$ in the low category and the rest is medium. This suggests that the cognitive aspects of the ability of empathy for elementary students in respondents is low. The instrument item (scale) in this aspect is about the individual's ability to understand the reasons for other individuals experiencing feelings of shame, anger, pride, sadness and crying.

In the affective aspects in the low category there were as many as $39.3 \%$, medium $43,9 \%$ and high $16.8 \%$. In the affective category the respondents were quite a lot in the high and medium categories. Prosocial motivation also has quite a high category of $19.6 \%$, medium $50.5 \%$ and low $29.9 \%$. This is different from the cognitive aspects which have nothing at all that has a high aspect and only slightly in the medium category.

The causes for this aspect are closely related to the ability to think. In the cognitive development of elementary school students (SD) is not so complex compared to the next phase which is able to think 
abstractly. According to Piaget aged 7-11 years in general, children at this stage have understood logical operations with the help of concrete objects (Santrock, 2002).

The difference in empathy profile is obtained from the factors that distinguish the formation process. The development of empathy is influenced by many factors, three of which are environment and parenting patterns and environmental settings. Research on the development of empathy is influenced by the environment and it is known to children that prosocial behavior is driven by empathy (Supeni, 2014). This is what can cause at the same age the condition of empathy in a country or region can have a different profile.

In addition to the above factors, the size of empathy can also be caused by gender. In the table of analysis of empathy based on gender in figure graph 5.6, it shows that porphyry is a character of empathy. Data that has a quite striking difference is in the cognitive and prosocial aspects while the affective is relatively the same.

Based on these data it can be seen that in the cognitive aspect data the total number of respondents or $\mathrm{N}$ is 643. Respondents are grouped into two characteristics, namely 322 male respondents and 321 female respondents. In male respondents in the cognitive aspects of respondents or $70.2 \%$ in the low category while in women only $54.5 \%$.

Differences in empathy can occur due to gender differences. This is in line with research said about women showed a greater difference between friend and enemy than men (Rueckert, Branch, \& Doan, 2011). In the other study showed results that women are more empathic than men (Toussaint \& Webb, 2005).

In this study, male respondents in prosocial motivation aspects $32.0 \%$ of respondents were in the low category. At high categories as much as $18.3 \%$. On prosocial motivation aspects $27.7 \%$ of respondents were in the low category. In the high category as much as $20.9 \%$. This also shows that there is a big difference in empathy gained in aspects of prosocial motivation.

Research conducted by (Asih \& Pratiwi, 2010) found other results, that there was a significant positive relationship between empathy, emotional maturity, gender on prosocial behavior. Another study was conducted by (O'Brien, Konrath, Grühn, \& Hagen, 2013) the results that women reported having a high empathy score compared to men in generating prosocial behavior.

Wuying, Jiamei, Lianqi \& Wenyi examined empathy for gender. Wuying, there is a difference between Empathy in elementary and middle school age. Four differences in gender are influenced by two factors. The first factor is physical maturity. As you get older, hormones between women and men are different. Women have more oxytocin, which has a positive influence on empathy. While men have more testosterone, which negatively affects empathy (Firdayani, 2015).

\section{Conclusions}

Based on the results and discussion, the character profile of empathy for fourth grade of elementary school students in DKI Jakarta was obtained, amounting to 643 with 322 male respondents and 321 female respondents. In the measurement of empathy using the EmQue-CA scale the results obtained were divided into 3 aspects, namely affective, cognitive and social motivation. The lowest aspect based on the overall analysis is the aspect of cognitive empathy by $62.4 \%$ of respondents in the low category, $37.6 \%$ in the moderate category and $0 \%$ in the high category. The empathy profile of female students is better than male students on cognitive aspects and prosocial motivation and there are relatively no significant differences in the categories of affection.

\section{Acknowledgments}

This work was supported by the Faculty of Education Jakarta State University. The researcher presents sincere appreciation to Yung-Ting Tsou from Leiden University who has allowed to use his questionnaire. This research also would not be possible without help, support and patience of my colleagues. 


\section{References}

A.P., N., C., R., S.C.P.M., T., W., S., E., D., J.J., B., ... Frijns, J. H. M. (2015). Low empathy in deaf and hard of hearing (pre)adolescents compared to normal hearing controls. PloS One. https://doi.org/10.1371/journal.pone.0124102

Asih, Y. G. \&, \& Pratiwi. (2010). Kematangan Emosi. Jurnal Psikologi Universitas Muria Kudus, I(1), 3342. Retrieved from http://eprints.umk.ac.id/268/1/33_-_42.PDF

Baron-Cohen, S., \& Wheelwright, S. (2004). The empathy quotient: An investigation of adults with asperger syndrome or high functioning autism, and normal sex differences. Journal of Autism and Developmental Disorders. https://doi.org/10.1023/B:JADD.0000022607.19833.00

Eisenberg, N., \& Miller, P. A. (1987). The Relation of Empathy to Prosocial and Related Behaviors. Psychological Bulletin. https://doi.org/10.1037/0033-2909.101.1.91

Fatimatuzzahro, A., Nimah Suseno, M., \& Irwanto, B. (2018a). Efektivitas Terapi Empati Untuk Menurunkan Perilaku Bullying Pada Anak Usia Sekolah Dasar. Jurnal Petik, 3(2), 1. https://doi.org/10.31980/jpetik.v3i2.145

Fatimatuzzahro, A., Nimah Suseno, M., \& Irwanto, B. (2018b). EFEKTIVITAS TERAPI EMPATI UNTUK MENURUNKAN PERILAKU BULLYING PADA ANAK USIA SEKOLAH DASAR. JURNAL PETIK. https://doi.org/10.31980/jpetik.v3i2.145

Firdayani. (2015). Pengembangan Empati Pada Anak Usia Sekolah Dasar, 978-979. Retrieved from http://mpsi.umm.ac.id/files/file/125-130 Fidrayani.pdf

Jolliffe, D., \& Farrington, D. P. (2006). Examining the relationship between low empathy and bullying. Aggressive Behavior. https://doi.org/10.1002/ab.20154

Nurhidayati, T. (2012). Empati dan Munculnya Perilaku Altruistik pada Masa Remaja. Edu-Islamika, 4(No. 01 Maret).

O’Brien, E., Konrath, S. H., Grühn, D., \& Hagen, A. L. (2013). Empathic concern and perspective taking: Linear and quadratic effects of age across the adult life span. Journals of Gerontology Series B Psychological Sciences and Social Sciences. https://doi.org/10.1093/geronb/gbs055

Olweus, D. (1997). Bully/victim problems in school: Facts and intervention. European Journal of Psychology of Education. https://doi.org/10.1007/BF03172807

Overgaauw, S., Rieffe, C., Broekhof, E., Crone, E. A., \& Güroglu, B. (2017). Assessing empathy across childhood and adolescence: Validation of the empathy questionnaire for children and adolescents (EmQue-CA). Frontiers in Psychology. https://doi.org/10.3389/fpsyg.2017.00870

Rieffe, C., Ketelaar, L., \& Wiefferink, C. H. (2010). Assessing empathy in young children: Construction and validation of an Empathy Questionnaire (EmQue). Personality and Individual Differences, 49(5), 362-367. https://doi.org/10.1016/j.paid.2010.03.046

Rueckert, L., Branch, B., \& Doan, T. (2011). Are Gender Differences in Empathy Due to Differences in Emotional Reactivity? Psychology. https://doi.org/10.4236/psych.2011.26088

Santrock, J. (2002). Life-span Development Perkembangan Hidup Jilid 1 Edisi Kelima. Jakarta: Erlangga.

Supeni, M. (2014). Empati Perkembangan Dan Pentingnya dalam Kehidupan Bermasyarakat. Jurnal Psikologi.

Toussaint, L., \& Webb, J. R. (2005). Gender differences in the relationship between empathy and forgiveness. Journal of Social Psychology. https://doi.org/10.3200/SOCP.145.6.673-686 